- FINANSE I PRAWO FINANSOWE.

- Journal of Finance and Financial Law •

Czerwiec/June 2020 • vol. 2(26): 99-114

https://doi.org/10.18778/2391-6478.2.26.07

\title{
PANDEMIA CZY WOJNA POKOLEŃ?
}

\author{
Jan Krzysztof Solarz \\ Wydziału Nauk o Zarządzaniu i Bezpieczeństwie, Społeczna Akademia Nauk \\ ORCIN: https://orcid.org/0000-0001-6528-7645
}

Krzysztof Waliszewski

Instytut Finansów, Uniwersytet Ekonomiczny w Poznaniu

ORCID: https://orcid.org/0000-0003-4239-5875

\section{Streszczenie}

Artykuł dotyczy pandemii koronawirusa COVID-19 i jego potencjalnego wpływu na gospodarkę, system finansów publicznych oraz finanse osobiste. Szok związany z wybuchem i ekspansją wirusa w skali globalnej stawia przez gospodarkami, finansami publicznymi i systemami zdrowotnymi ogromne wyzwania związane z groźbą recesji, drastycznego zmniejszenia dochodów osobistych w gospodarstwach domowych, konieczność opracowania programów rządowych, łagodzących skutki pandemii oraz włączenia się Banku Centralnego w postaci obniżki stóp procentowych i stopy rezerwy obowiązkowej, a także uruchomienia niestandardowych instrumentów polityki monetarnej tzw. luzowania ilościowego (QE). Celem opracowania jest zaproponowanie języka nanofinansów do opisania pandemii jako destrukcji mechanizmu solidarności międzypokoleniowej i wewnątrzpokoleniowej. Główną hipotezą badania jest, że jakość zarządzania ryzykiem finansowym codzienności przesądzi o skali strat finansowych oraz czasie niezbędnym do wyjścia z załamania społeczno-gospodarczego wywołanego pandemią.

Słowa kluczowe: pandemia COVID-19, finanse osobiste, zarządzanie kryzysowe, nanofinanse.

JEL Class: I18, K36, D14, H12. 


\section{WSTĘP}

Zaraza jest jedną z form urzeczywistnienia się ryzyka systemu zdrowotnego, zdrowia publicznego. Dotychczasowa wiedza o zarządzaniu ryzykiem systemowym wskazuje, że ma ono wyraźne etapy. Pierwszy z nich to poszukiwanie analogii do znanych z przeszłości epidemii. Formalna nazwa koronawirusa SARS-CoV-2 nawiązuje do epidemii SARS. Wiemy, że była to zaraza, która sama po 18 miesiącach wyczerpała zdolność do ekspansji i tli się jako MERS na Półwyspie Arabskim. Tego typu identyfikacja ryzyka systemowego łatwo prowadzi do błędu poznawczego. Zło przychodzi z zewnątrz i pełna izolacja od zewnętrznych kontaktów sprawę rozwiąże.

Drugi etap to pomiar tak zdefiniowanego ryzyka. Standardową metodą pomiaru ryzyka jest metoda Value at Risk. Współcześnie zostaje ona wzbogacona o metodę czarnego tabędzia, pomiaru szkód, które wyrządza zjawisko bardzo mało prawdopodobne - pandemia COVID-19, lecz obejmujące całą ludzkość. Zgodnie $\mathrm{z}$ dorobkiem nanofinansów straty tej zarazy polegają na zablokowaniu transferów międzypokoleniowych, co paraliżuje funkcjonowanie rodziny. Są one ogromne, bo rodziny dysponują ogromnymi zasobami majątkowymi. Oficjalne metody wyceny strat z powodu pandemii w 95\% odnoszą się do wyceny kosztu śmierci 7 milionów ludzi, co oznacza utratę od 3,5 do 4\% GNI (Światowego Produktu). Przy umiarkowanej pandemii $40 \%$ strat to utracone zarobki $(0,4$ do $1 \%$ GNI) [Fan i in. 2016].

Dolegliwość pandemii mierzy się przy pomocy dolegliwości dla systemu publicznej służby zdrowia. Gdy zarażony jest 1\% ludności, to jest poważne wyzwanie dla systemu zdrowia publicznego. Przy 10\% zarażonej ludności infrastruktura kadrowa i finansowa systemu zdrowotnego się rozpada i nie jest zdolna do pełnienia swoich funkcji zapewnienia bezpieczeństwa zdrowotnego kraju [Atkeson 2020].

Trzeci etap to walka o to, kto zapłaci za szkody poczynione przez pandemię koronawirusa? Trwa przesuwanie napięć z finansów publicznych na rynek pracy oraz płynności finansowej publicznych systemów emerytalnych oraz gospodarstw domowych.

Celem opracowania jest zaproponowanie języka nanofinansów do opisania pandemii jako destrukcji mechanizmu solidarności międzypokoleniowej i wewnątrzpokoleniowej. Główną hipotezą badania jest wykazanie, że jakość zarządzania ryzykiem finansowym codzienności przesądzi o skali strat finansowych oraz czasie niezbędnym do wyjścia z załamania społeczno-gospodarczego wywołanego pandemią. 


\section{POZNAWCZA PERSPEKTYWA ZARZĄDZANIA PANDEMIA}

Nauki społeczne definiują chorobę jako brak zdrowia. W tej perspektywie pandemia jest wynikiem naruszenia pewnych norm społecznych. Jedną z nich jest przekonanie, że za bezpieczeństwo ekonomiczne i zdrowotne odpowiada państwo. Inną, że zdrowy styl życia jest obowiązkiem obywatela.

W powszechnej świadomości, pandemia koronawirusa jest wynikiem działania ludzi bogatych. Starzy stanowią większość pasażerów statków wycieczkowych, a one stały się rozsadnikiem epidemii. Młodzi włóczą się po świecie i stykają się z nieznanymi krajowej służbie zdrowia chorobami.

Tabela 1 przedstawia grupy obwiniane jawnie i skrycie przez większość obywateli o rozpowszechnianie koronawirusa.

Tabela 1. Grupy naruszające normy zdrowia publicznego

\begin{tabular}{|c|c|c|}
\hline Pandemia & Starzy & Młodzi \\
\hline Bogaci & Chciwi & Egoiści \\
\hline Biedni & Wykluczeni & Niedostosowani \\
\hline
\end{tabular}

Źródło: opracowanie własne.

Pogoń za przygodą w ciepłych krajach powoduje, że choroby są rozwlekane przez statki wycieczkowe i samoloty czarterowe. Młodzi chcieli jeździć na nartach we Włoszech i oglądać mecze piłkarskie w Hiszpanii i stali się ogniskami epidemii, tak samo jak wielotysięczne spotkanie sekty religijnej w Seulu.

Biedni są nosicielami zarazy jedynie wówczas, kiedy mają bezpośredni kontakt $\mathrm{z}$ innymi ludźmi.

W modelu wyjaśniania rozpowszechnienia epidemii COVID-19 zasadnicze znaczenie ma fakt, że niekontrolowane rozpowszechnienie zarazy prowadzi do podwojenia liczny osób zarażonych co 4 do 7 dni. Zachowanie dystansu spolecznego powoduje, że liczba osób zarażonych w danym okresie mieści się w zdolności ich hospitalizowania przez służbę zdrowia, zarówno prywatną, jak i publiczną. Zbyt wczesne zniesienie restrykcji sanitarno-epidemiologicznych może spowodować powstanie kolejnej fali pandemii [Anderson i inni 2020].

Ryzyko epidemiologicznie nieracjonalnego zmiękczenia lub zniesienia zasad zachowania dystansu społecznego wynika z presji młodych na odzyskanie płynności finansowej. Podstawowym kanałem jej utrzymania są transfery od dziadków. Pomocniczym kanałem zarządzania płynnością finansową młodych są lombardy i zastawianie smartfonów. 


\section{METODY WALKI Z PANDEMIA}

Podobnie jak istnieją mity na temat tego, kto wywołał pandemie, tak istnieją stereotypy jak należy pokonać jej społeczno-ekonomiczne następstwa. Recepta jest prosta, po pierwsze pieniądze, po drugie pieniądze i po trzecie pieniądze.

Tabela 2 zawiera przegląd proponowanych metod walk z pandemią. Zostały one zróżnicowane z punktu widzenia przewidywanej długości występowania pandemii. Jeśli mieści się w okresie do trzech miesięcy to jest rozwiązywana metodami emocjonalnymi, mobilizacją społeczną i solidarnością pobudzoną przez strach o istnienie. Jest to znany w literaturze System I. W przypadku przedłużenia się trwania pandemii uruchamia się System II, zimnej i racjonalnej kalkulacji, ustalania nowych zasad gry społecznej.

Tabela 2. Zarządzanie systemowe ryzykiem koronawirusa

\begin{tabular}{|c|c|c|}
\hline $\begin{array}{c}\text { Pandemia } \\
\text { cel przetrwanie }\end{array}$ & System I (do $3 \mathrm{~m})$ & System II (do 18 m) \\
\hline $\begin{array}{c}\text { Generowanie } \\
\text { pieniędzy }\end{array}$ & $\begin{array}{c}\text { Publiczny } \\
\text { - elektronicznych } \\
\text { pieniędzy NBP }\end{array}$ & $\begin{array}{c}\text { Prywatnych - elektronicznych pieniędzy } \\
\text { niebankowych pośredników finansowych }\end{array}$ \\
\hline SME & $\begin{array}{c}\text { Zwolnienie z danin } \\
\text { publicznych }\end{array}$ & $\begin{array}{c}\text { Zmiany strukturalne } \\
\text { ( sektory: realne - wirtualne) }\end{array}$ \\
\hline $\begin{array}{c}\text { Wiarygodności } \\
\text { kredytowej kraju }\end{array}$ & $\begin{array}{c}\text { Utrzymanie potencjału } \\
\text { rozwojowego }\end{array}$ & Nowa specjalizacja międzynarodowa Polski \\
\hline Przetrwania rodu & $\begin{array}{c}\text { Płynność finansowa } \\
\text { rodziny }\end{array}$ & Sprawiedliwe transfery międzypokoleniowe \\
\hline
\end{tabular}

Źródło: opracowanie własne.

Panuje powszechne, błędne przekonanie, że wirus przenosi się za pomocą gotówki i bilonu [Auer i in. 2020]. W praktyce Chin banknoty były sterylizowane przed ponownym dopuszczeniem do obrotu pieniężnego. Trwają intensywne prace nad emisją detalicznych pieniędzy elektronicznych emitowanych przez Banki Centralne, m.in. na podstawie rachunków indywidualnych w Banku Centralnym. Dla potencjalnych użytkowników elektronicznych pieniędzy emitowanych przez bank centralny, kluczowy jest koszt transakcyjny tego nowego instrumentu płatniczego. Szacunki Banku Centralnego Kanady mówią, że użytkownik tego pieniądza zyskałby od 0,60 do 1,63 CAD miesięcznie po wprowadzeniu tego typu pieniądza opartego o technologię blockchain [Huynhc i in., 2020]. 


\section{WPŁYW PANDEMII NA FINANSE GOSPODARSTW DOMOWYCH - PRÓBA OCENY}

Pierwsze dane dotyczące konsumpcji przez gospodarstwa domowe w 3 i 4 tygodniu marca 2020 r. w Polsce, czyli po wprowadzeniu przez rząd restrykcyjnych ograniczeń związanych z epidemią (zamknięte zostały m.in. sklepy w galeriach, restauracje, kina) wskazują na jej zmniejszenie w stosunku do 3 i 4 tygodnia lutego 2019 r. o ok. 30\%, a efekt kupowania „na zapas” nie jest widoczny. Ostatnie 2 tygodnie marca 2020 r. oznaczają ziszczenie się czarnego scenariusza dla Amerykanów, którzy lawinowo tracą pracę - liczba nowych osób bez pracy zwiększyła się z 282 tys. osób w tygodniu przed wybuchem pandemii, poprzez 3,3 mln osób w pierwszym tygodniu, $6,6 \mathrm{mln}$ osób w drugim tygodniu pandemii i 6,7 mln osób w trzecim tygodniu pandemii. Zaledwie w ciągu 21 dni liczba Amerykanów bez pracy zwiększyła się do blisko $17 \mathrm{mln}$ osób, czyli $10 \%$ amerykańskiego rynku pracy. Uchwalony przez Kongres plan pomocy gospodarce opiewa na kwotę ponad 2 bln USD. Państwa G-20 przeznaczyły natomiast 5 bln USD na ratowanie światowej gospodarki przed skutkami pandemii COVID-19. W gospodarstwach domowych, pozostających w dobrowolnej lub przymusowej kwarantannie i pracujących zdalnie, maleje zapotrzebowanie na paliwa, przy spadającej jego cenie w związku z sytuacją na rynku ropy naftowej. Pandemia koronawirusa poważnie zaczyna nadszarpywać budżety gospodarstw domowych, a także obnaża negatywne konsekwencje braku planowania i kontrolowania budżetów oraz tworzenia rezerw i oszczędności buforowych, które można byłoby wykorzystać w okresie kryzysu. Wskazuje również na deficyty w zarządzaniu ryzykiem codzienności przez polskie gospodarstwa domowe w okresie prosperity. Wpływ pandemii na poszczególne gospodarstwa domowe i ich finanse nie będzie jednakowy, a determinantami różnicującymi będą zapewne branża zatrudnienia, rodzaj zatrudnienia (etat, własna działalność gospodarcza), liczba osób w gospodarstwie, średni poziom wynagrodzeń, status rodzinny. Ponadto inwestorzy indywidualni posiadający lokaty kapitału na giełdzie również realizują straty w związku $\mathrm{z}$ historycznie najniższymi notowaniami walorów na rynku publicznym, odzwierciedlonych $\mathrm{w}$ indeksach koniunktury giełdowej.

Negatywnymi konsekwencjami utraty pracy lub obniżenia zarobków dotknięte będą całe gospodarstwa domowe osób pracujących w działach szczególnie narażonych na kryzys. Odrębną kwestią jest wykluczenie w zakresie edukacji prowadzonej zdalnie przez uczniów nieposiadających dostępu do internetu lub wystarczającej liczby komputerów w domu, gdy rodzice pracują zdalnie, a rodzeństwo ma obowiązek zdalnej nauki. To rodzi ryzyka i napięcia w zakresie korzystania z pomocy społecznej i funduszy publicznych dla łagodzenia negatywnego wpływu pandemii. Często rodzice na emeryturze będą utrzymywać niepracujące dzieci, co oznacza transfery międzypokoleniowe między nimi. 
Tabela 3. Ryzyko finansowe w gospodarstwach domowych w wyniku pierwszej fali konsekwencji gospodarczych pandemii COVID-19 według kategorii miejsca zamieszkania

\begin{tabular}{|c|c|c|c|c|c|c|}
\hline \multirow{2}{*}{ Grupa ryzyka } & \multicolumn{5}{|c|}{ Miasta - liczba mieszkańców w tys. } & \multirow{2}{*}{ Wieś } \\
\hline & Powyżej 500 & $200-500$ & $100-200$ & $20-100$ & $0-20$ & \\
\hline \multicolumn{7}{|c|}{ Wszystkie Gospodarstwa Domowe } \\
\hline \multicolumn{7}{|c|}{ Pracujący na umowę o pracę w działach szczególnie zagrożonych } \\
\hline Odsetek gospodarstw domowych (\%) & 12,37 & 12,75 & 13,05 & 12,44 & 11,72 & 11,04 \\
\hline \multicolumn{7}{|c|}{ Pracujący z inną umową lub samozatrudnieni w działach szczególnie zagrożonych } \\
\hline Odsetek gospodarstw domowych (\%) & 6,63 & 5,75 & 4,54 & 4,73 & 5,10 & 4,76 \\
\hline \multicolumn{7}{|c|}{ Pracujące Gospodarstwa Domowe } \\
\hline \multicolumn{7}{|c|}{ Pracujący na umowę o pracę w działach szczególnie zagrożonych } \\
\hline Odsetek gospodarstw domowych (\%) & 17,06 & 18,74 & 19,72 & 19,29 & 17,94 & 14,88 \\
\hline \multicolumn{7}{|c|}{ Pracujący z inną umową lub samozatrudnieni w działach szczególnie zagrożonych } \\
\hline Odsetek gospodarstw domowych (\%) & 9,14 & 8,45 & 6,86 & 7,34 & 7,82 & 6,41 \\
\hline
\end{tabular}

Źródło: Myck i in. 2020a.

Tabela 4. Ryzyko finansowe w gospodarstwach domowych w wyniku pierwszej fali konsekwencji gospodarczych pandemii COVID-19 według decylowych grup dochodowych

Grupa ryzyka

\begin{tabular}{|c|c|c|c|c|c|}
\hline \multicolumn{7}{|c|}{ Grupy decylowe } \\
\hline 1 & 2 & 3 & 4 & 5 & 6 \\
\hline
\end{tabular}

\section{Wszystkie Gospodarstwa Domowe}

Pracujący na umowę o pracę w działach szczególnie zagrożonych

Odsetek gospodarstw domowych (\%)

\begin{tabular}{|r|r|r|r|r|r|}
\hline 4,30 & 5,80 & 10,15 & 12,18 & 15,45 & 15,93 \\
\hline
\end{tabular}

Pracujący z inną umową lub samozatrudnieni w działach szczególnie zagrożonych

\begin{tabular}{|l|r|r|r|r|r|r|}
\hline Odsetek gospodarstw domowych (\%) & 2,85 & 2,67 & 4,82 & 4,61 & 4,54 & 6,10 \\
\hline
\end{tabular}

\section{Pracujące Gospodarstwa Domowe}

Pracujący na umowę o pracę $\mathrm{w}$ działach szczególnie zagrożonych

\begin{tabular}{|l|r|r|r|r|r|r|}
\hline Odsetek gospodarstw domowych (\%) & 8,16 & 12,88 & 18,12 & 19,57 & 22,67 & 22,01 \\
\hline
\end{tabular}

Pracujący z inną umową lub samozatrudnieni w działach szczególnie zagrożonych

\begin{tabular}{|l|r|r|r|r|r|r|}
\hline Odsetek gospodarstw domowych $(\%)$ & 5,42 & 5,94 & 8,59 & 7,40 & 6,66 & 8,43 \\
\hline
\end{tabular}

Źródło: Myck i in. 2020a. 
Tabela 5. Ryzyko finansowe w gospodarstwach domowych w wyniku pierwszej fali konsekwencji gospodarczych pandemii COVID-19 według typów rodzin

\begin{tabular}{|c|c|c|c|c|c|c|}
\hline \multirow[b]{2}{*}{ Grupa ryzyka } & \multicolumn{6}{|c|}{ Kategorie rodzin } \\
\hline & $\begin{array}{c}\text { Osoby } \\
\text { samotne }\end{array}$ & $\begin{array}{l}\text { Samotni } \\
\text { rodzice }\end{array}$ & $\begin{array}{c}\text { Małżeństwa } \\
\text { bez dzieci }\end{array}$ & $\begin{array}{c}\text { Małżeństwa } \\
\text { z dziećmi }\end{array}$ & $\begin{array}{l}\text { Osoby } \\
\text { samotne } \\
60 / 65+\end{array}$ & $\begin{array}{c}\text { Małżeństwa } \\
60 / 65+\end{array}$ \\
\hline \multicolumn{7}{|c|}{ Wszystkie Rodziny } \\
\hline \multicolumn{7}{|c|}{ Pracujący na umowę o pracę w działach szczególnie zagrożonych } \\
\hline $\begin{array}{l}\text { Odsetek gospodarstw } \\
\text { domowych }(\%)\end{array}$ & 9,69 & 18,32 & 11,68 & 16,06 & 0,26 & 0,35 \\
\hline \multicolumn{7}{|c|}{ Pracujący z inną umową lub samozatrudnieni w działach szczególnie zagrożonych } \\
\hline $\begin{array}{l}\text { Odsetek gospodarstw } \\
\text { domowych }(\%)\end{array}$ & 3,33 & 4,88 & 4,67 & 7,61 & 0,32 & 0,58 \\
\hline \multicolumn{7}{|c|}{ Rodziny Pracujące } \\
\hline \multicolumn{7}{|c|}{ Pracujący na umowę o pracę w działach szczególnie zagrożonych } \\
\hline $\begin{array}{l}\text { Odsetek gospodarstw } \\
\text { domowych }(\%)\end{array}$ & 13,19 & 24,87 & 13,91 & 16,43 & 4,77 & 3,69 \\
\hline \multicolumn{7}{|c|}{ Pracujący z inną umową lub samozatrudnieni w działach szczególnie zagrożonych } \\
\hline $\begin{array}{l}\text { Odsetek gospodarstw } \\
\text { domowych (\%) }\end{array}$ & 4,54 & 6,62 & 5,56 & 7,78 & 5,92 & 6,16 \\
\hline
\end{tabular}

Źródło: Myck i in. 2020a.

Z pierwszych badań wynika, że w czasie pandemii znacząco wzrosła liczba pracowników realizujących swoje obowiązki zawodowe w $100 \%$ zdalnie, a najistotniejszą trudnością był brak kontaktów społecznych oraz odizolowanie. Jednocześnie, choć praca zdalna w czasie pandemii w większym stopniu umożliwiła godzenie obowiązków zawodowych i osobistych, to także w większym stopniu skutkowała zacieraniem się granicy między pracą a życiem prywatnym [Dolot 2020].

Według danych z Badania Budżetów Gospodarstw Domowych z 2018 r., gospodarstwa prawie 330 tys. uczniów nie są wyposażone w komputer $\mathrm{z}$ dostępem do Internetu, a w przypadku kolejnych 1320 tys. uczniów liczba komputerów w ich gospodarstwach jest mniejsza niż liczba uczniów. Ponadto 7,1\% gospodarstw domowych zamieszkanych przez uczniów nie posiada komputera lub pokrewnego urządzenia $\mathrm{z}$ dostępem do Internetu, w tym $30 \%$ na wsi, a w przypadku 17,3\% gospodarstw łączna liczba tych urządzeń w gospodarstwie domowym jest mniejsza niż liczba mieszkających w nich uczniów. Oznacza to skalę wykluczenia edukacyjnego na poziomie ponad 1,65 mln, co stanowi ponad 35\% wszystkich uczniów w Polsce [Myck i in. 2020b]. 
Jak wskazują badania potencjalnych skutków pierwszego etapu pandemii na finanse gospodarstw domowych, opracowane w oparciu o dane z Badania Budżetów Gospodarstw Domowych GUS:

- największy odsetek gospodarstw domowych z osobami szczególnie narażonymi na negatywne konsekwencje pandemii jest w miastach powyżej 500 tys. mieszkańców i wynosi on $6,6 \%$, biorąc pod uwagę wszystkie gospodarstwa, a biorąc pod uwagę tylko gospodarstwa, w skład których wchodzą osoby pracujące, sięga $9,1 \%$, odpowiednio $12,4 \%$ i $17,1 \%$ osób zatrudnionych jest w zagrożonych sektorach na podstawie umowy o pracę (tabela 3);

- najwięcej narażonych na negatywne konsekwencje pierwszej fali gospodarczych skutków pandemii jest wśród gospodarstw średniozamożnych. W 6. grupie decylowej wśród gospodarstw z przynajmniej jedną osobą pracującą $8,5 \%$ stanowią gospodarstwa, których członek pracuje w zagrożonych działach na umowę inną niż umowa o pracę lub jako osoba samozatrudniona. Łącznie z członkami gospodarstw zatrudnionymi w tych działach gospodarki na umowę o pracę ten odsetek przekracza $30 \%$ (tabela 4);

- wśród rodzin, w których przynajmniej jedna osoba jest aktywna zawodowo, najwięcej takich gospodarstw jest $\mathrm{w}$ grupie rodziców samodzielnie wychowujących dzieci, wśród których aż 31,5\% pracuje w działach szczególnie zagrożonych, a $6,6 \%$ pracuje na podstawie innych umów niż umowa o pracę lub prowadzi działalność gospodarczą (tabela 5).

Podjęcie przez banki centralne i banki komercyjne prac nad zmniejszeniem skutków pandemii koronawirusa dla gospodarstw domowych posiadających kredyty konsumpcyjne i hipoteczne doprowadziło do wypracowania stanowiska, polegającego na propozycji wakacji kredytowych w zakresie rat kapitałowych/kapitałowo-odsetkowych przez 3 miesiące, a w niektórych przypadkach 6 miesięcy. Może to rodzić dla gospodarstwa domowego dodatkowe koszty odsetkowe oraz koszty związane z wydłużeniem okresu ważności zabezpieczeń o czas wakacji kredytowych i odraczać faktyczne problemy z obsługą zadłużenia w czasie. Obniżenie przez NBP dwukrotnie stóp procentowych, w tym stopy lombardowej i stopy depozytowej oznacza zmniejszenie części odsetkowych rat kredytowych, ale jednocześnie przy rosnącej inflacji powoduje drastyczny spadek oprocentowania lokat bankowych oraz ich ujemną realną rentowność. $Z$ drugiej strony, gwałtowne umocnienie się franka szwajcarskiego względem złotówki drastycznie pogarsza sytuację klientów posiadających kredyty denominowane w tej walucie nie tylko poprzez wzrost wysokości raty miesięcznej, ale całkowitego zadłużenia do spłaty. Również środowisko instytucji pożyczkowych zaproponowało odroczenie spłaty całości lub części raty o stosowny okres na dostatecznie udokumentowany wniosek klienta. Faktyczny poziom osób tracących pracę będzie uzależniony od dostępności narzędzi tzw. tarczy antykryzysowej o wartości $220 \mathrm{mld}$ zł dla mikroprzedsiębiorstw oraz tarczy antykryzysowej 2.0 dla średnich przedsiębiorstw 
o wartości 100 mld zł, a także chęci korzystania z nich przez beneficjentów. NBP wdraża również niestandarodwe instrumenty polityki pieniężnej. Szeroki zakres wykluczenia cyfrowego, rozumianego nie jako dostęp do sieci internetowej, ale posiadanie kompetencji cyfrowych, czyli umiejętności posługiwania się nowoczesnymi technologiami aktywnie w codziennym życiu dla korzystania z usług prywatnych i admi-nistracji publicznej wśród polskich gospodarstw domowych nie pozwala na efektywną pracę zdalną ${ }^{1}$. Jak wskazano na wykresie 1 , co trzeci polski zatrudniony ma niskie ogólne kompetencje cyfrowe, w UE jest to co piąta osoba. Jak wskazuje wykres 2, polscy pracownicy znacznie rzadziej niż pracownicy UE15 mogą wykazać się ponadpodstawowymi kompetencjami cyfrowymi (18 $-38 \%)$.

Gospodarstwa domowe, nieposiadające żadnych oszczędności, będą miały problemy z utrzymaniem płynności finansowej, a np.: poprzez utratę pracy lub zawieszenie działalności gospodarczej pojawią się u nich problemy związane z pokrywaniem bieżących zobowiązań, w tym pożyczkowo-kredytowych, wykluczonych z sektora bankowego ze względu na utratę głównego źródła dochodu.

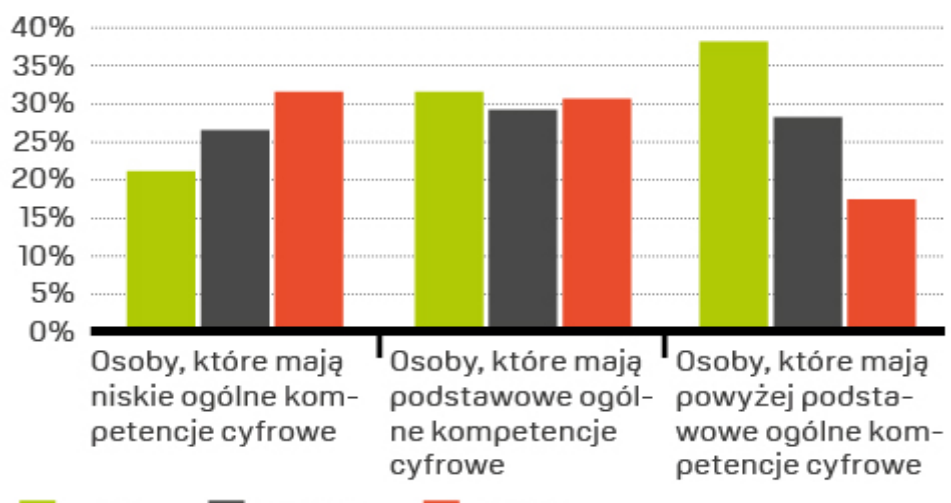

Wykres 1. Poziom ogólnych kompetencji cyfrowych w krajach UE

Źródło: Blim 2018 [dostęp 4.04.2020].

${ }^{1}$ Kompetencje cyfrowe to podstawowe umiejętności pozwalające na komunikowanie, pozyskiwanie informacji oraz tworzenie treści w środowisku cyfrowym. Do bardziej zaawansowanych kompetencji cyfrowych, cenionych wśród pracodawców, należą kompetencje odnoszące się m.in. do specyficznych zastosowań ICT (Information and Communication Technologies - technologie informacyjno-komunikacyjne) w różnych obszarach działalności pracowniczej i biznesowej, np. zarządzanie finansami, kontaktami z klientem i procesami logistycznymi [Majos 2017]. 


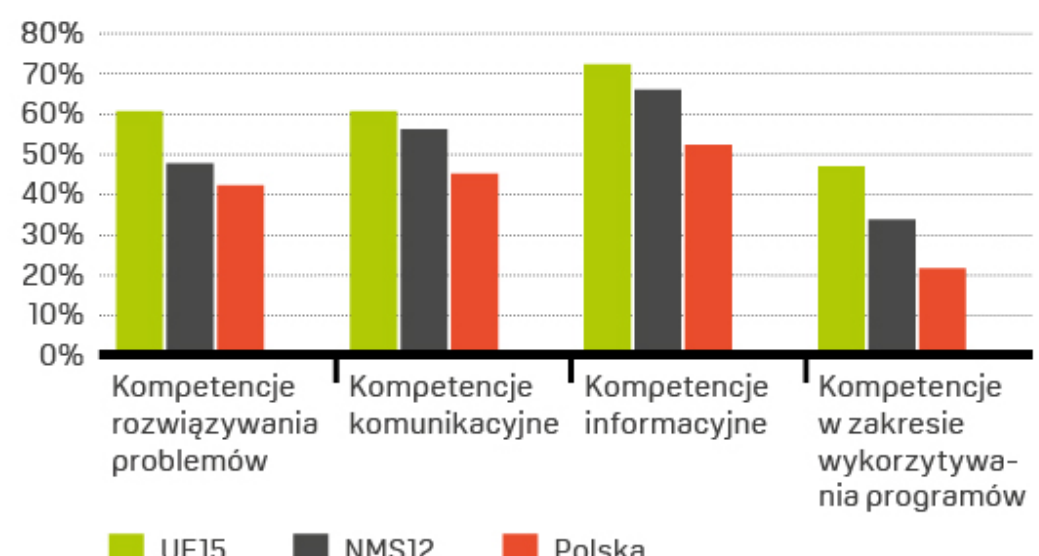

Oznaczenia dla wykresu 1 i 2:

UE15 (tzw. stara Unia, czyli kraje, które przystąpiły do Unii Europejskiej przed 2004 r.), NMS12 (New Member States - kraje, które przystępowały do Unii od 2004 r. - bez Polski), Polska, jako wyodrębniona kategoria informacyjna.

Wykres 2. Poziom ponadpodstawowych kompetencji cyfrowych ${ }^{2}$ w krajach UE

Źródło: Blim 2018 [dostęp 4.04.2020].

W ramach ustaw związanych z tzw. tarczą antykryzysową obowiązujących od kwietnia 2020 r. nastąpiła zmiana limitu maksymalnych kosztów pozaodsetkowych kredytu konsumenckiego. Motywacją dla zmiany obecnie obowiązujących przepisów było przeciwdziałanie pobierania nadmiernych kosztów od osób, które mają problemy finansowe będące konsekwencją koronawirusa. Pomimo sprzeciwu branży pożyczkowej i trzech działających na nich związków pracodawców - Polskiego Związku Instytucji Pożyczkowych, Związku Przedsiębiorstw Finansowych i Fundacji Rozwoju Rynku Finansowego przepisy antylichwiarskie weszły w życie w następującym kształcie:

- dla kredytów o okresie spłaty nie krótszym niż 30 dni oblicza się według wzoru:

$\mathrm{MPKK} \leq(\mathrm{K} \times 15 \%)+(\mathrm{K} \times \mathrm{n} / \mathrm{R} \times 6 \%) \leq 45 \% \mathrm{~K}$ w całym okresie kredytowania,

${ }^{2}$ Obejmują one tworzenie prezentacji lub dokumentów tekstowych, zdjęć, tabel i wykresów, używanie zaawansowanych funkcji arkusza kalkulacyjnego do porządkowania i analizowania danych, napisanie kodu w języku programowania. 
- dla kredytów o okresie spłaty krótszym niż 30 dni oblicza się według wzoru:

$$
\mathrm{MPKK} \leq \mathrm{K} \times 5 \%
$$

gdzie:

MPKK - maksymalna wysokość pozaodsetkowych kosztów kredytu,

$\mathrm{K}$ - całkowita kwota kredytu,

$\mathrm{n}$ - okres spłaty wyrażony w dniach,

$\mathrm{R}$ - liczba dni w roku.

Takie ograniczenie kosztów pozaodsetkowych może ograniczyć dostęp do pożyczek pozabankowych wielu osobom, które zmuszone sytuacją będą zasilały podziemie kredytowe i lombardy. Jak wskazują statystyki BIK za 2020 r., pogłębia się zaobserwowana już na przełonie 2019 i 2020 r. recesja na rynku pożyczek pozabankowych w Polsce [Waliszewski 2020], szczególnie po wprowadzeniu zmian związanych z ograniczeniem kosztów pozaodsetkowych.

Zmniejszenie mobilności osób w każdym wieku w okresie pandemii może w przyszłości przekładać się na większe ryzyko zachorowań na dolegliwości krążenia i układu ruchu, a zamknięcie osób starszych w ich mieszkaniach przyczynia się do ich alienacji i zwiększa poczucie osamotnienia. Zamknięcie przychodni i oddziałów szpitali powoduje przesunięcie planowanych zabiegów i badań, a to oznacza kryzys służby zdrowia po okresie epidemii, która już przed nią nie była w najlepszej kondycji organizacyjnej i finansowej. Zaostrzenie przez banki w Polsce polityki w zakresie udzielania kredytów hipotecznych m.in. poprzez zwiększenie poziomu wymaganego wkładu własnego przy ogólnej niepewności co do przyszłości wieszczy poważne spadki cen nieruchomości na rynku mieszkaniowym, które przed wybuchem pandemii notowały historyczne maksima. Dane z marca 2020 r. odnośnie liczby wniosków kredytowych na kredyty hipoteczne w porównaniu z rokiem poprzednim wskazują na spadek o 7,6\% r/r [BIK, 2020a]. W przypadku kredytów ratalnych udzielanych za pośrednictwem dużych sieci handlowych oraz e-commerce, finansujących zakup takich dóbr jak elektronika, sprzęt AGD, meble, samochody, zmniejszenie liczby zapytań jest jeszcze większe i wynosiło odpowiednio 33,4\% r/r w ostatnim tygodniu marca $2020 \mathrm{r}$. oraz $38,5 \% \mathrm{r} / \mathrm{r}$ w pierwszym tygodniu kwietnia $2020 \mathrm{r}$. [BIK, 2020b].

Badanie przeprowadzone przez $4 \mathrm{P}$, omnibus CAWI, na reprezentatywnej próbie 1010 Polaków w wieku 18-75 lat, w dniach 25-27 marca 2020 r. dla BIG InfoMonitor wskazuje, że Polacy obawiają się zarówno problemów zdrowotnych, jak i finansowych w związku z pandemią koronawirusa (wykres 3). 


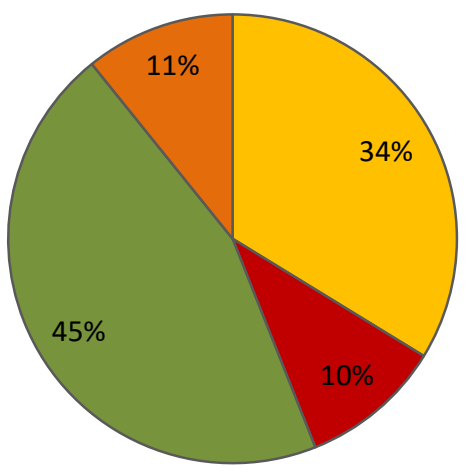

$\square$ zdrowotnych $\quad$ finansowych $\square$ ijednych i drugich $\square$ żadnych

Wykres 3. Jakich problemów obawiasz się w związku z epidemią koronawirusa? Źródło: Koronawirus odbiera pracę..., 2020 [dostęp 14.04.2020].

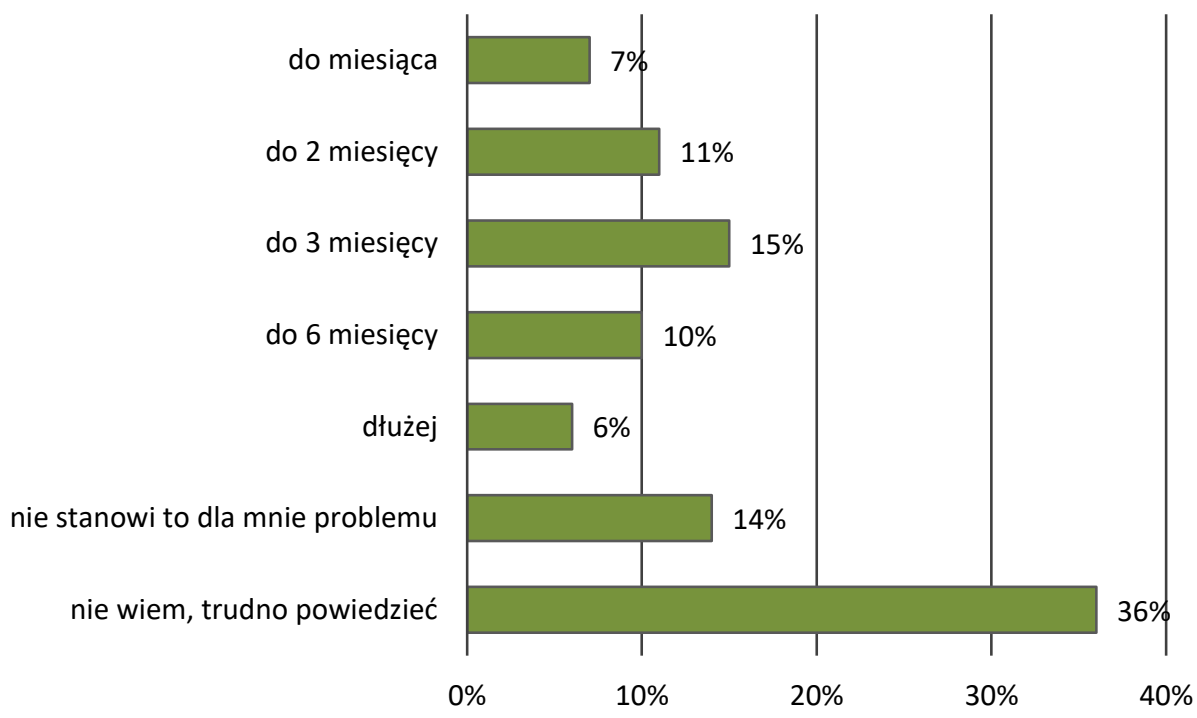

Wykres 4. Jaki okres pandemii wytrzyma Twój budżet zanim pojawią się problemy finansowe? Źródło: Koronawirus odbiera pracę..., 2020 [dostęp 14.04.2020]. 
Niemal co piąty badany informuje bowiem, że ma pieniądze najwyżej na jeden lub dwa miesiące, zbliżony jest też udział przewidujących, którzy deklarują, że oszczędności wystarczą im na trzy miesiące. Najsilniejszy lęk o finanse przeżywają obecnie osoby, które nie mają do dyspozycji żadnych odłożonych pieniędzy, ewentualnie najwyżej jednomiesięczne dochody - to w tej grupie aż 36\% odpowiada, że w bezruchu wywołanym koronawirusem wystarczy im pieniędzy maksymalnie na dwa miesiące (wykres 4).

\section{SCENARIUSZE ROZWOJU PANDEMII KORONAWIRUSA}

Wirtualne spotkanie przywódców państw G-20 pozwoliło na ustalenia listy priorytetów $\mathrm{w}$ walce $\mathrm{z}$ pandemią:

- Ochrona życia,

- Zapewnienie pracy i dochodów,

- Odbudowa zaufania, utrzymanie stabilności finansowej, powrót na ścieżkę wzrostu i mocne ożywienie,

- Minimalizacja zaburzeń w handlu oraz globalnych łańcuchach dostaw,

- Zagwarantowanie pomocy krajom potrzebującym,

- Skoordynowanie działań w zakresie zdrowia publicznego i finansów [G-20 2020].

Analitycznie te cele można podzielić na dwie grupy. Pierwsza związana z przezwyciężeniem rozprzestrzeniania się paniki, druga z scenariuszami odbudowy aktywności gospodarczej.

Tabela 6 dostarcza ram poznawczych dla uporządkowania praktyki zarządzania ryzykiem systemowym pandemii.

Tabela 6. Praktyka zarządzania ryzykiem systemowym

\begin{tabular}{|c|c|c|}
\hline Istota ryzyka systemowego & System I & System II \\
\hline Panika & Polaryzacja & Nacjonalizm gospodarczy \\
\hline Szok asymetryczny & Scenariusze: V,VV, L & Wojna pokoleń \\
\hline
\end{tabular}

Źródła: opracowanie własne.

Lęk przed śmiercią wśród seniorów i inwalidztwem wśród młodzieży prowadzi do wypłukania warstwy średniej z życia gospodarczego i społecznego. Silna polaryzacja wprost prowadzi do zaniku poczucia solidarności opartej o wspólnotę losu. Rodzi się pokusa odgrodzenia się od innych granicami.

Część decydentów wierzy, że gwałtowne wysłanie popytu i podaży na kwarantannę szybko się zakończy i równie szybko gospodarka wróci do poprzedniego poziomu aktywności. Część uważa, że obecnie dokonują się głębokie zmiany 
strukturalne, przechodzimy od realnej do wirtualnej rzeczywistości. Oznacza to, że zniknie popyt na pracę ze względów technologicznych, a nie braku efektywnego popytu na dany typ usług. Pesymiści uważają, że kapitalizm platform będzie funkcjonował w warunkach strukturalnej stagnacji wywołanej przez starzenie się społeczeństw.

Perspektywa nonofinansów uznaje, że to co obserwujemy jest pierwszą odsłoną wojny pokoleń, którą definiujemy jako brak możliwości osiągnięcia jakości życia pokolenia odchodzącego z życia przez pokolenie cyfrowo wykształcone, ale pozbawione widoków na dobrą pracę i życie [Bangham 2020]. Kryzys gospodarczy wywołany pandemią całkowicie odmieni sytuację związaną z długiem publicznym. W ciągu ostatniego stulecia poważne kryzysy światowe często prowadziły zarówno do zaciągania przez rządy pożyczek na dużą skalę, jak i do zmian - często radykalnych - w ich sposobie postępowania z wierzycielami. Walka z COVID-19 prawdopodobnie nie będzie stanowić wyjątku. Opracowywane obecnie plany ratowania gospodarki prawdopodobnie przyćmią plany zastosowane w czasie kryzysu finansowego; wartość programu amerykańskiego może sięgnąc ok. 10\% PKB. Załamanie produkcji i wpływów podatkowych również może być większe, zaś zadłużenie przynajmniej kilku gospodarek zapewne znacznie przekroczy $150 \%$ PKB [The Economist 2020].

\section{PODSUMOWANIE}

Wiedza i umiejętności zarządzania ryzykiem systemowym doprowadziły do stwierdzenia, że o stabilności globalnego systemu finansowego decydują nawyki finansowe miliardów ludzi. Obecnie sukces $\mathrm{w}$ walce $\mathrm{z}$ pandemią koronawirusa zależy od zmiany nawyków zdrowotnych ludzkości. Warto zatem wykorzystać doświadczenia zarządzania ryzykiem systemowym do analizy COVID-19. Pandemia koronawirusa oznacza szok podażowy i popytowy dla gospodarek, okres zastoju ma wpływ na sytuację finansową gospodarstw domowych i ich aktywność na rynku pracy. Wychodzenie z obecnego kryzysu będzie zapewne trwało wiele miesięcy, a ostateczne koszty pandemii zostaną podzielone pomiędzy sektor prywatny i publiczny. Presja na zmianę nawyków otwiera pole dla systemowego budowania zaufania poprzez wykorzystanie technologii blockchain do inicjowania kontaktów i płatności typu P2P, B2B oraz C2C. Tektoniczne przesuniecie ze świata rzeczywistości realnej do wirtualnej tworzy warunki do emisji przez NBP pieniądza elektronicznego kreowanego przy wykorzystaniu powszechnego rachunku osobistego w NBP. 


\title{
BIBLIOGRAFIA
}

Anderson R.M., Heersterbeek H., Klinkenber D., Hollingsworth D.T., 2020, How will country-based mitigation measures influence the course of the covid-19 epidemic? „The Lancet”, March.

Atkeson A., 2020, What will be ten economic impact of COVID-19 in the US? Rough estimates of disease scenarios, ,NBER Working Paper”, no. 26867.

Auer R., Cornelli G., Frost J., 2020, Covid-19, cash, and the future of payments, „BIS Bulletin”, no. 3 .

Banham G., 2020, In this coronavirus crisis, do families have enough savings to make ends meets?, Resolution Foundation.

BIK, 2020a, BIK Indeks - Popyt na Kredyty Mieszkaniowe wynióst w marcu 2020 r. (-3,1\%), 6.04.2020.

BIK, 2020b, Koronawirus a popyt na kredyty ratalne, 8.04.2020.

Blim M., 2018, Pracownik i jego kompetencje cyfrowe, 1.03.2018, https://aspolska.pl/pracownik-ijego-kompetencje-cyfrowe/ [dostęp 4.04.2020].

Dolot A., 2020, Wplyw pandemii COVID-19 na prace zdalna-perspektywa pracownika, „E-mentor", nr 1.

Fan V.Y., Jamison D.T., Summers L.H., 2016, The inclusive cost of pandemic influenza risk, „NBER Working Paper", no. 22137.

G-20, 2020, Statement on COVID-19, BIS.

How to pay for the pandemic, 2020, „The Economist”, 25.03.2020.

Huynh K.P., Molnar J., Shcherbakov O., Yu Q., 2020, Demand for Payment Services and Consumer Welfare: The Introduction of a Central Bank Digital Currency, „Bank of Canada Staff Working Paper", no. 7.

Koronawirus odbiera pracę i pustoszy portfele Polaków, 2020, https://media.bik.pl/informacje-prasowe/498172/koronawirus-odbiera-prace-i-pustoszy-portfele-polakow [dostęp 14.04.2020].

Majos A., 2017, Kompetencje cyfrowe pracowników MŚP. Polska na tle UE, „Biuletyn Euro-Info”, nr 1.

Myck M., Oczkowska M., Trzciński K., 2020a, Skala ryzyka finansowego dla gospodarstw domowych: pierwsza fala konsekwencji gospodarczych pandemii COVID-19, Centrum Analiz Ekonomicznych, Komentarze CenEA, 22.03.2020.

Myck M., Oczkowska M., Trzciński K., 2020b, Zamknięte szkoły: warunki uczniów do nauki zdalnej $w$ okresie pandemii COVID-19, Centrum Analiz Ekonomicznych, Komentarze CenEA, 28.03.2020.

Waliszewski K., 2020, Determinanty recesji na rynku pożyczek pozabankowych w Polsce, „Finanse i Prawo Finansowe", nr 1(25).

\section{PANDEMIC OR GENERATIONAL WAR?}

\begin{abstract}
The article deals with the COVID-19 coronavirus pandemic and its potential impact on the economy, public finance system and personal finances. The shock of the virus outbreak and expansion on a global scale poses enormous challenges to economies, public finances and health systems related to the threat of recession, drastic reduction in personal income in households, the need to develop government programs mitigating the effects of a pandemic, and the central
\end{abstract}


bank joining in the form of rate cuts interest and reserve requirements, as well as the launch of non-standard monetary policy instruments quantitative easing (QE). The aim of the study is to propose a language of nanofinance to describe a pandemic as a destruction of the mechanism of intergenerational and intra-generational solidarity. The main hypothesis of the study is that the quality of financial risk management of everyday life will determine the scale of financial losses and the time necessary to overcome the socio-economic collapse caused by a pandemic.

Keywords: COVID-19 pandemic, personal finances, crisis management, nanofinance. 